\title{
Development and Utilization of Sports Tourism Resources of Yunnan Hani Nationality Based on SWOT Analysis
}

\author{
Zhu Luxiao \\ Scientific Research Department of Yunnan Normal University, Kunming of Yunnan 650500, China
}

Keywords: Yunnan Hani Nationality; sports tourism resources; SWOT analysis; development and utilization

Abstract: SWOT strategic analysis method is utilized for comprehensively analyzing traditional sports resources of Yunnan Hani Nationality, thereby providing reference for sports tourism resources development and utilization of Yunnan Hani Nationality. Advantages, disadvantages, opportunities and challenges for product development of Hani nationality sports tourism resources are analyzed. SWOT matrix analysis and countermeasure map for product development of Hani nationality sports tourism resources is drawn. Internal condition factor (advantages and disadvantages) and external environment factor (opportunities and threats) affecting product development of Hani nationality sports tourism resources are analyzed mainly. Two major factors are combined for analysis, thereby obtaining countermeasures and measures for product development of Hani nationality sports tourism resources.

\section{Introduction}

Hani nationality has rich sports tourism resources, mainly including wrestling, catapult, archery, shouldering, and fighting in mud and other comparative sports tourism resources. Research on development of minority sports tourism resources in Yunnan is hotspot and difficult ${ }^{[1]-[5] .}$ In Literature [2], SWOT method is utilized for studying strategies of developing sports tourism resources in Yunnan Honghe Autonomous Prefecture. In Literature [3], SWOT method is utilized for studying development of minority traditional sports tourism resources in Yunnan. In Literature [5], SWOT method is utilized for studying sports tourism development countermeasures in Yunnan, etc. SWOT method has become an effective method for studying development of sports tourism resources products, macro-development strategies or policies are classified for studying some minority sports tourism resources in Yunnan or some administrative regions of Yunnan till present on the one hand; special report for studying product development of Hani nationality sports tourism resources is not available till present on the other hand. Results of the sixth nationwide population census show that: Yunnan Hani nationality population is 1.63 million, which ranks No. 2 among Yunnan minority population, there are 20 counties in Yunnan with Hani nationality population of more than 5000. SWOT analysis, literature data and other methods are utilized in the paper for studying sports tourism resources product development of Yunnan Hani nationality accordingly in the paper. 


\section{Advantages for Product Development of Hani Nationality Sports Tourism Resources}

\subsection{Special location advantages of Hani nationality habitation}

Yunnan Hani Nationality mainly lives in the south of Yunnan. Southern Yunnan area belongs to low latitude plateau monsoon activity area with vast territory, complex and diversified climate categories. It has mountain three-dimensional climate characteristics 'four seasons in one mountain, and different weathers within ten miles'. Meanwhile, Southern Yunnan is connected with Vietnam, Myanmar and Laos, which is known as 'enriched' south of colorful clouds. Hani nationality's ethnic characteristic sports events are combined with the unique natural scenery in Southern Yunnan organically due to unique natural conditions and regional advantages, thereby forming unique natural and humanism tourism resources in Southern Yunnan. In addition, the authenticity of Hani nationality's national sports events is kept in good condition due to special natural conditions.

\subsection{Resources and environment advantages of Hani nationality habitation}

Southern Yunnan for Hani nationality and Yi nationality includes more than ten ndigenous nationalities, namely Han nationality, Hani nationality, Yi nationality, Miao nationality, Dai nationality, Zhuang nationality, Yao nationality, Hui nationality, Buyi nationality, Lahu nationality, Bulang nationality (Mang people), etc. All ethnic groups have their own representative traditional sports tourism activities, Hani nationality sports culture is mutually integrated with sports cultures of other ethnic groups, new sports culture resources are further generated, and the resources abundance is relatively high. Rich national traditional sports events bring large scale benefits to the productization of sports tourism resources and development of tourism, thereby providing resources basic conditions for realizing synergistic development.

\subsection{Special village traditional culture advantages of Hani nationality}

Hani nationality villages are mainly located in mountainous area and semi-mountainous area, which are characterized by blocked terrain, inconvenient transportation and relatively good traditional village culture reservation. Traditional sports events exit based on religious sacrifice, festival activities, etc., such as pile wearing for sacrificing god, pile wearing becomes an important sport event, which becomes an indispensable sports event in religious sacrifices, festivals and daily recreation activities. In addition, Manggu is an ancient drum specially for the family. Each Qiboran (Hani language, grandfather's descendants) has several customs and rules for enhancing cohesion, such as mutual protection and aid obligations between members of families, joint dining system in marriage funeral etiquette ritual activities, etc. [4]. The unique Hani nationality traditional custom culture gives people a sense of mystery and attraction, which can attract a large number of customers for the development of national sports tourism resources.

\subsection{Rich humanism sports tourism resources of Hani nationality}

Hani nationality is mainly distributed in Honghe County, Yuanyang County, Luchun County, Jiangcheng County, Mojiang, Pingbian County, Jinping County and other Hani nationality areas in Southern Yunnan. Hani nationality has many sports tourism resources, mainly including wrestling and arbalest in comparative category, swing, gyro playing, lifting, etc. in game category, Manggu dancing, Silver Pheasant dancing, creeper dancing, etc. in dance category, Manggu dancing, palm fan dancing and martial arts in performance category, music dancing, straw bale throwing, etc. in festival category, etc. 


\section{Opportunities for Product Development of Hani Nationality Sports Tourism Resources}

\subsection{Benefits of sports tourism industry policies are constant.}

General Administration of Sport of China and National Tourism Administration cooperated and signed 'Cooperative agreement about driving integration development of sports tourism' on May 15, 2016. Both parties jointly established 'National leading group of sports tourism work', they jointly organized to formulate 'National outline of sports tourism development', etc. The State Council printed and issued "Health China 2030' planning outline' on October 25, 2016. It released 'Guidance of General Office of the State Council about accelerating development of fitness and leisure industry' on October 28, 2016 (Guo Ban $\mathrm{Fa}$ [2016] No. 77), and requirements are proposed for construction and development of sports tourism. CPC Yunnan Committee and provincial government seriously implement the spirit of important speech given by General Secretary Xi Jinping during investigation in Yunnan. They actively serve and integrate into national 'One Belt One Road', thereby fully exerting important supporting role in constructing a radiation center to South and South-east Asia. In 'Several suggestions of CPC Yunnan Committee and Yunnan People's Government about mainly driving the development of key industries, massive health and tourism culture are listed as Yunnan advantageous key industry with foundation and market prospect, which can form new power of economic growth more rapidly.

\subsection{The public has increasing demand on health.}

Tourism is one of the fastest growing and most dynamic industries all over the world at present People are gradually putting more time and income into tourism, fitness, entertainment and other sports tourism activities with the rapid advance of comprehensive construction of a well-off society. Sports tourism will become important content of public life, which becomes an important symbol of the well-off society. Huge potential market and demand will rapidly promote the development of sports tourism industry, thereby providing a once-in-a-lifetime market development opportunity for product development of Hani nationality sports tourism resources, and becoming a new growth point of tourism economy. Hani nationality habitation areas have rich mountain resources endowment conditions, which contain huge market potential and development prospect of product development of Hani nationality sports tourism resources

\subsection{Western sports tourism ushers great development.}

National western development strategy provides the western sports tourism resources product development with historic opportunities. The state must provide sufficient capital, infrastructure as well as other support and guarantees for developing western sports tourism industry. Yunnan belongs to the scope of western development, and a series of preferential policies about western development bring infinite opportunities for Hani nationality sports tourism resources product development ${ }^{[5]}$. Honghe Hani nationality and Yi nationality autonomous prefecture is adopted as an example. It receives 23.15 million overseas tourists in 2015, the foreign exchange income was \$112 million, and the number of domestic tourists was 25.6399 million with an increase of 21.4 percent over the previous year. State tourism revenue reached 19.15 billion yuan with an increase of 21.5\% over the previous year. The growth of customer traffic provides a large number of customers to development of Honghe national sports tourism. There are 60 tourism star-rated hotels, 17 tourism scenic areas, 37 travel agencies, 11 tourist shopping places and 2 tourist automobile companies. Public service facilities are developed for creating sound basic conditions for developing Hani nationality sports Tourism resources. 


\section{Threats for Product Development of Hani Nationality Sports Tourism Resources}

\subsection{Other competitive threats for sports tourism resources development}

Because Southern Yunnan is the 'enriched' south of colorful clouds, there are many kinds of sports tourism resources in Southern Yunnan. Various sports tourism resources of Southern Yunnan have both mutual reflection cooperative relationship and mutually replaced competitive relationship. Southern Yunnan has very rich sports tourism resources. Although Hani nationality's tourism resources have some special events, they still have certain gap from other well-developed national sports tourism resources in leisure tourism resources endowment, leisure equipment and services, visibility, reputation and recognition, etc. Meanwhile, since they have insignificant characteristics and advantages, some customer markets are divided by Dai nationality sports tourism events in Southern Yunnan. A lot of customer market shares are occupied by Lijiang, Dali, Shangri-la and other regions in Western Yunnan. Development for other minority sports tourism resources forms competitive threat to product development of Hani nationality sports tourism resources.

\subsection{Threats of tourism growth to environment}

The main impact of tourism activities on the environment includes water pollution, garbage pollution and other damage to natural environment. Since Hani nationality sports tourism resources and natural resources are organically combined into a whole in Southern Yunnan, product development and effective utilization of Hani nationality sports tourism resources must attract a lot of tourists. Increase of tourists must bring sound economic benefits to Southern Yunnan on the one hand, and it must produce certain influence on environment of Southern Yunnan, especially scenic spots on the other hand, and certain damage even can be damaged. How to solve the contradiction between development of sports tourism and environment protection has been an important topic for local governments at all levels, tourism management departments, environmental protection departments, etc.

\section{Matrix Analysis and Countermeasure for Product Development of Hani Nationality Sports Tourism Resources}

SWOT matrix analysis and countermeasure map of product development of Hani nationality sports tourism resources is drawn according to the above analysis (Table 1). Countermeasure and measures corresponding to $\mathrm{S}+\mathrm{O}, \mathrm{S}+\mathrm{T}, \mathrm{W}+\mathrm{O}$ and $\mathrm{W}+\mathrm{T}$ four-quadrants are respectively obtained through analysis aiming at four dimensions in the matrix (please see table 1). Table 1 shows that internal condition factor (advantages and disadvantages) and external environment factor (opportunities and threats) mainly affect product development of Hani nationality sports tourism resources. Two major factors are combined for analysis, thereby obtaining countermeasures and measures for product development of Hani nationality sports tourism resources.

\section{Conclusion}

Yunnan Hani Nationality has rich rich sports culture resources, however there are still many to-be-developed sports tourism resources till present. SWOT matrix analysis and countermeasure map for product development of Hani nationality sports tourism resources is drawn in the paper. Internal condition factor (advantages and disadvantages) and external environment factor (opportunities and threats) affecting product development of Hani nationality sports tourism resources are analyzed mainly. Two major factors are combined for analysis, thereby obtaining 
countermeasures and measures for product development of Hani nationality sports tourism resources. Hani nationality resources product development can be based on natural resources sight-seeing tourism. Ornamental and participation sports tourism events of Hani nationality traditional sports undergo product development. Hani nationality village traditional ritual culture, etc. Can be regarded as the support for overall planning. The ritual events of village traditional ritual culture can be utilized for better displaying Hani nationality traditional sports culture.

\section{References}

[1] Zhu Luxiao, Wang Ting, Zhang Lei. Research on evaluation of product development of Yunnan Dai nationality sports tourism resources. Journal of Yunnan Normal University (Natural Science Edition), 2017, 37 (4):

[2] Ou Yunhai, Fang Chengjun, Su Ronghui, etc. SWOT analysis of autonomous prefecture sports tourism of Honghe Hani nationality and Yi nationality. Journal of Honghe College, 2012, 10 (6): 123-125

[3] Deng Kaimin. Research on utilization and development of Yunnan minority traditional sports tourism resources; Beijing: Beijing Sport University, 2011.

[4] Li Zixian, Li Qibo. Collected papers of the first Hani nationality culture international colloquium. Kunming: Yunnan Ethnic Publishing House, 1996

[5] Chen Baosheng. On development status and countermeasures of Yunnan sports tourism. Bulletin of Sport Science \& Technology, 2009, 17 (8): 104-106.

Table1 Matrix analysis of product development of Hani nationality sports tourism resources

\begin{tabular}{|c|c|c|}
\hline & advantages (Strengths) & disadvantages (Weaknesses) \\
\hline $\begin{array}{l}\text { External } \\
\text { analysis }\end{array}$ & $\begin{array}{l}\text { (1) Special location advantages of } \\
\text { habitation; (2) Resources and } \\
\text { environment advantages of } \\
\text { habitation; } \\
\text { (1) Special village traditional } \\
\text { culture; } \\
\text { (4) Rich humanism sports tourism } \\
\text { resources; }\end{array}$ & $\begin{array}{l}\text { (1) Economic underdevelopment } \\
\text { restricts product development of } \\
\text { resources; } \\
\text { (2) Resources development is lack } \\
\text { of overall planning; } \\
\text { (3) Professionals are deficient. }\end{array}$ \\
\hline Opportunities & $\mathrm{S}+\mathrm{O}$ countermeasure & $\mathrm{W}+\mathrm{O}$ countermeasure \\
\hline $\begin{array}{l}\text { (1) Advantageous } \\
\text { sports tourism industry } \\
\text { policies are constant; } \\
\text { (2) the public has } \\
\text { increasing demand on } \\
\text { health; (3) Western } \\
\text { sports tourism ushers } \\
\text { great development; }\end{array}$ & $\begin{array}{l}\text { (1) The government, sports } \\
\text { departments, tourism departments, } \\
\text { etc. should strengthen cooperation, } \\
\text { and effectively use resources } \\
\text { advantages, market demand and } \\
\text { advantageous policy for making } \\
\text { resources effectively serve economic } \\
\text { and social development; } \\
\text { (2) The development of national } \\
\text { sports tourism resources should be } \\
\text { strengthened; }\end{array}$ & $\begin{array}{l}\text { (1) The advantageous policy } \\
\text { should be controlled well. } \\
\text { Top-level design should be done } \\
\text { well, development opportunities } \\
\text { and conditions should be obtained } \\
\text { from governments at all levels; } \\
\text { (2) Market opportunities should } \\
\text { be seized for fully developing } \\
\text { sports tourism improving } \\
\text { comprehensively and } \\
\text { service capability and level; }\end{array}$ \\
\hline Threats & $\mathrm{S}+\mathrm{T}$ countermeasure & $\mathrm{W}+\mathrm{T}$ countermeasure \\
\hline $\begin{array}{l}\text { (1) Competitive threats } \\
\text { for developing other } \\
\text { sports tourism } \\
\text { resources; (2) Threats } \\
\text { of tourism growth to } \\
\text { environment; }\end{array}$ & $\begin{array}{l}\text { (1) Resources advantages are exerted } \\
\text { for developing high-quality, unique } \\
\text { and irreplaceable sports tourism } \\
\text { events; } \\
\text { (2) The relationship between sports } \\
\text { tourism resources development and } \\
\text { environmental protection is } \\
\text { scientifically managed through } \\
\text { overall planning; }\end{array}$ & $\begin{array}{l}\text { (1) High-quality professional are } \\
\text { cultivated with more efforts; } \\
\text { (2) Concepts are updated for } \\
\text { enhancing innovation } \\
\text { consciousness, improving the } \\
\text { innovation ability, continuously } \\
\text { enhancing the management } \\
\text { quality and management level, } \\
\text { and comprehensively improving } \\
\text { the influence of sports tourism } \\
\text { events; }\end{array}$ \\
\hline
\end{tabular}

